\title{
The ethical approach to AIDS: a bibliographical review
}

\author{
C Manuel, P Enel, J Charrel, D Reviron, M P Larher, X Thirion, J L Sanmarco Marseille, France
}

\section{Authors' abstract}

This bibliographical study involved first the exploitation of four data-banks: Medline, CNRS, Bioethics and AIDS, with the following key words (in conjunction with AIDS): ethics, human rights, confidentiality, legislation, jurisprudence. A total of 412 references were listed between 1983 and the end of 1987.

Examination of the quantitative increase of articles over these years shows that, while references to AIDS and/or $H I V$ infection - referred to as 'AIDS' for brevity increased by about one third per year, the number of papers treating ethical problems linked to AIDS doubled each year. This increase makes it clear that these problems are important and pressing, that they are evolving rapidly and can be given no easy solution.

After reading and analysis of accessible articles in readily comprehensible languages, the different themes can be classified in two categories:

\section{1 - Measures intended to protect society} (starting with the most coercive)

- quarantine and isolation;

- discriminatory measures concerning specific groups;

- non-respect of the confidential nature of medical

information;

- application of the penal code;

- screening;

- obligatory declaration and registration;

- testing of blood given by donors;

- vaccination and medical innovations, therapeutic assays; - information, education.

\section{2-Measures intended to protect the individual}

- fundamental rights of the patient: his/her right to confidentiality, to information and to treatment;

-civil rights: civil liberty, right to education, right to work, etc...

- rights of the healthy individual: right of those in contact with the patients, safety of hospital staff, of those receiving blood-transfusions, etc...

The legislation adopted in the various countries and the

\section{Key words}

AIDS: ethics; AIDS: human rights; AIDS: confidentiality; HIV infection. main opinions to be found in these articles are listed and analysed, and for each particular theme it is possible to refer to a list of the 232 most important articles.

While the debate seems to concentrate on the conflict between the right of society to protect itself against the spread of infection and the 'civil' rights of the infected minorities, our conclusion tends to reduce this antagonism, showing that, particularly as far as the confidential nature of medical information is concerned, measures intended to protect the individual also protect society.

\section{Introduction}

From an ethical point of view, the problem raised by any epidemic appears to be the conflict between the right of society to protect itself against the spread of infection and the 'civil' rights of the minority groups hit by the epidemic. This is a truism, but it is at the core of the whole debate.

Sometimes the ethical problem does not arise, because the danger is so great that quarantine must be imposed: without question, violation of individual liberties is then legitimate (in the case of plague or smallpox, for example). Sometimes a preventive or therapeutic solution exists and can legitimately be made compulsory: compulsory vaccination, for instance, or treatment of venereal diseases.

However, in the case of AIDS, which, while extremely serious, does not spread like cholera or typhus, and for which no treatment is at present available, the debate is open.

The problem is complicated by an 'unpleasant' context defined by inhibitions concerning the most usual modes of infection. Notions of morality, of punishment, of puritanism, are linked with the desire to discriminate both against certain risk groups (homosexuals and drug addicts) and against certain ethnic groups (Africans, Haïtians). Such discrimination is even stretched sometimes to haemophilic children, who are refused admittance to school.

In such a context, and even in serious medical publications, certain authors soon began to call for extreme and extraordinarily repressive measures, such as quarantine or prison for seropositives, tattooing and even castration for risk-groups, refusal to treat infected patients, dismissal from work or living quarters. 
In reply to and in support of such proposals a great number of articles, arguments and legal drafts have appeared, which have been hotly debated. It therefore seemed of interest to us to consider this 'ethical' approach to AIDS and to try to take stock of the present situation. We refer to AIDS for brevity, even though some discussions more accurately concern HIV infection in non-symptomatic people.

\section{Material}

Four bibliographical data-banks were consulted: Medline, CNRS (Pascal), Bioethics, AIDS, and exploited with the key words (in conjunction with AIDS, of course), ethics, human rights, confidentiality, legislation, jurisprudence.

The exploitation covered the period from 1983 (first articles concerning AIDS) to October 1989:

- No language was excluded from the global study of references, but subsequently only articles in English, French and Italian were read and analysed.

- Once double references had been eliminated, there remained 850 references to a whole variety of sources, from the specialised article of 40 or 50 pages to editorials or even letters.

Some articles were not requested because of difficulty of translation (Swedish, Danish, Norwegian, German, Flemish). Some articles could not be found by our Inter-University Lending Library, even after research in London (British Library Lending Division) and in Switzerland (in the four university libraries). Thus 14 per cent of the articles were not analysed, half of these because of linguistic problems, and the other half for reasons of distribution.

\begin{tabular}{|c|c|c|c|c|c|c|}
\hline \multicolumn{7}{|c|}{ Number of publications per year } \\
\hline & 1983 & 1984 & 1985 & 1986 & 1987 & 1988 \\
\hline AIDS and ethics & 7 & 9 & 31 & 81 & 212 & 303 \\
AIDS & 534 & 887 & 1303 & 1989 & 3114 & 4794 \\
Ethics & 3299 & 3417 & 3743 & 4022 & 3869 & 4109 \\
$\begin{array}{c}\text { Total number of } \\
\text { publications analysed by } \\
\text { MEDLINE }\end{array}$ & 286799 & 296465 & 305036 & 314419 & 323203 & 347560 \\
\hline
\end{tabular}

^ Key-words given: Ethics, human rights, confidentiality, legislation, jurisprudence.

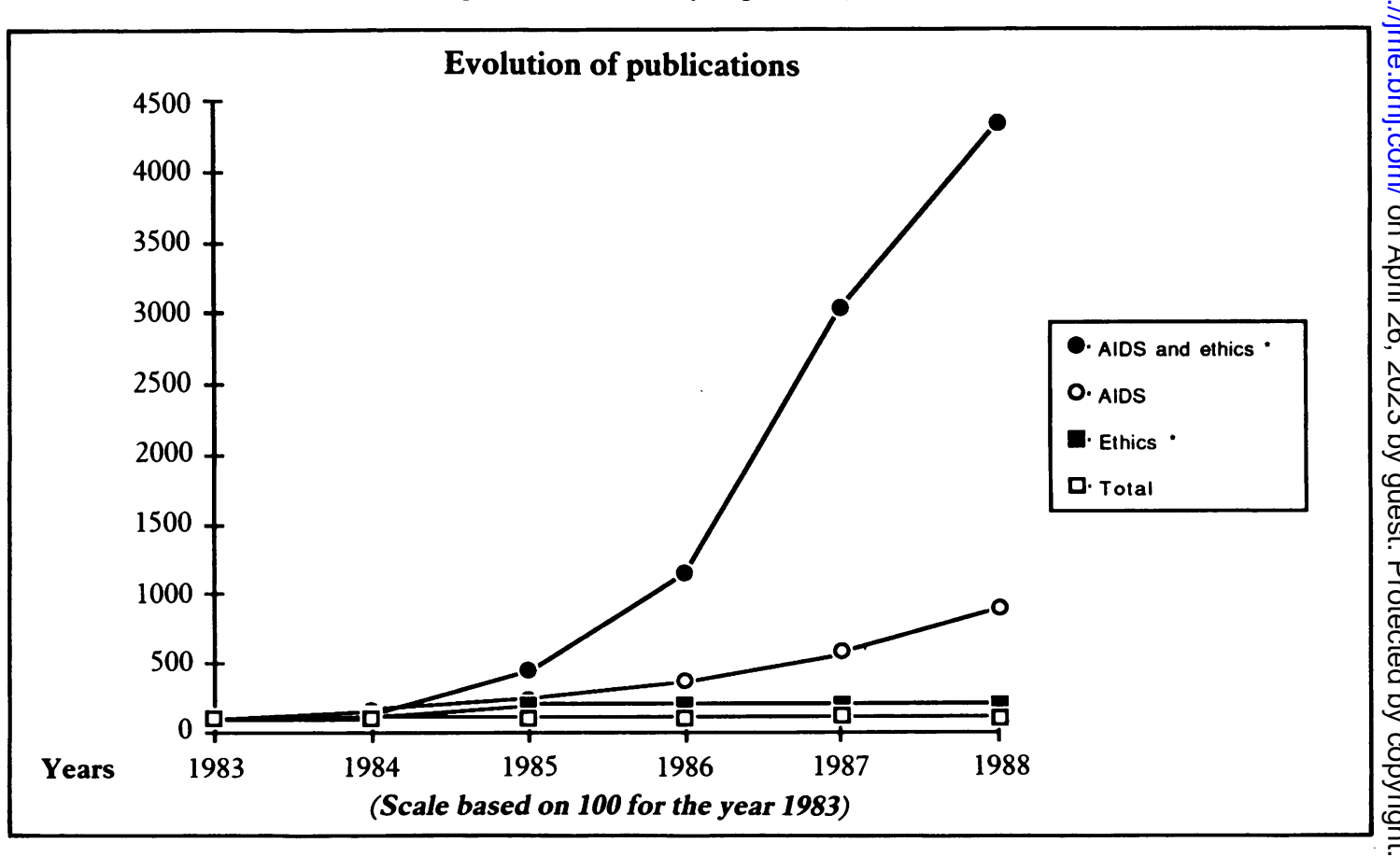




\section{Progression in quantity of the articles over the years}

\section{STUDY BASED ON REFERENCES SUPPLIED BY THE DATA-BANK MEDLINE}

Since our starting-point was the first appearance of the illness, it is interesting to note the quantitative progression of articles over the five years concerned. For a more subtle analysis we compared the statistics on ethics and AIDS with:

- the number of publications on AIDS;

- the number of publications on ethics;

- the total number of publications analysed by Medline.

The table giving the figures by year and by key word, and the graph giving the rates of increases of the references from 1983, show that:

- the number of publications analysed by Medline remains roughly the same;

- the same can be said of the publications on ethics;

- however, while the number of references to AIDS has been increasing by about one third per year since 1983, only publications concerning ethical questions linked to AIDS have doubled each year.

This very considerable increase indicates that we are dealing with important and pressing problems, which are evolving rapidly and which can be given no easy solution.

\section{Study of sources}

Study of the sources of the various references reveals a majority of medical journals ( 50 per cent), but also some scientific journals such as: Nature, Science (14 per cent); nursing periodicals ( 11 per cent); publications in the field of legal medicine ( 7 per cent), and of public health (6 per cent). Proportionally less important are journals of dentistry (3.5 per cent), psychiatry ( 2 per cent), micro-biology (1.5 per cent). Lastly, some references come from Christian publications ( 2 per cent), and some from the big daily or weekly publications such as the New York Times, Washington Post, Newsweek, The Times (2.5 per cent) (these last references being provided by the data-bank, Bioethics).

\section{STUDY OF MAIN THEMES}

After collecting the bibliographical documents, our analysis of the various themes, based on the most general articles $(1,2,3,4,5,6,7,8,9,10,11,12,13,14,15$, $16,17,18,19,20,21,22,23,24,25,26,27,28,29,30,31,32$, $33,34)$, led us to draw up the following plan:

- firstly, a review of legislation (or drafted legislation) tending to protect society by preventing the spread of the epidemic.
The consequence of these measures will almost always be, in varying degrees, violation of the civil rights of the carriers, of risk-groups, and sometimes of the ordinary individual.

- secondly and symmetrically, we will present everything that has been written or proposed concerning the protection of the individual.

\section{1 - Measures intended to protect society}

We will consider first the most coercive measures (quarantine) and work towards the most liberal (information, education).

QUARANTINE AND ISOLATION $(5,7,8,9,13,18,35,36$, $37,38,39,40,41,42,43,44$ )

This is obviously the solution that would best protect society against the spread of AIDS, but which implies, for the sick or sero-positive individual, the most fundamental violation of his freedom. While historical examples are many (diseases subject to quarantine, isolation of tuberculosis patients, compulsory treatment and hospitalisation for venereal diseases), the protection of others and the consequent violation of the patient's rights were accompanied in these cases by the hope of being treated and freed after cure.

In the case of AIDS, however, in the present therapeutic situation, isolation means isolation for life: restriction of freedom is extreme.

The case of AIDS can be compared to that of leprosy in the past: infection by repetitive contact can be regarded as equivalent to sexual transmission, and isolation in leper-colonies was more or less definitive.

When considering legislation on quarantine and isolation, we must distinguish between:

- countries and states which have devised special laws for AIDS (Sweden in 1985, Bavaria in 1987, Illinios in 1987);

- countries and states which have put AIDS on the lists of infectious or venereal diseases, or again on the list of 'to be declared' diseases, where previous laws on isolation will thus apply to AIDS (Ohio, Florida, Mexico, Iceland). In these legislations, quarantine for AIDS does not raise any particular legal problems, since it is already provided for in public health codes in cases of certain diseases: AIDS has only to be included in those lists. However, in the United States, the quarantine programme first proposed in Virginia did not 'pass' constitutional approval despite its popularity with the general public.

DISCRIMINATORY MEASURES CONCERNING CERTAIN GROUPS $(1,2,5,6,7,17,28,29,45,46,47,48,49,50,51,52$, $53,54,55,56,57)$

To be included in this section are all those problems linked with the exclusion of carriers or of members of riskgroups:

- exclusion from certain jobs $(5,17,40,53,54,58)$ : in all states of the USA the law forbids discrimination based on a handicap $(3,6,12,17,34,37,55,59,60)$, and 33 
states have accepted that AIDS be considered as a handicap. New specific legislation is generally opposed to discrimination, except in Georgia where, on the contrary, a ruling restricts protection of employees suffering from AIDS and allows an employer to require screening. In 1987 in Bavaria compulsory screening was introduced for Civil Service candidates and for future magistrates.

- dismissal of sero-positives from the US army.

- refusal of sero-positive children in public schools: several cases have been taken to court in the US $(32,57$, $61,62,63,64,65$ ).

- exclusion from certain means of transport: in February 1985 the air company Airlines was forced by public pressure to make a ruling forbidding the transport by air of AIDS patients.

- rejection by insurance companies (66): in the US, given the present health system, this can imply the refusal of the right to treatment.

- refusal of entry at frontiers $(5,48)$ : a number of countries and states have introduced systematic screening at frontiers for immigrants (USA, Arab countries, Bavaria, Thailand, USSR, China, Cuba). Legislation on immigrants and foreigners may seem the least likely to raise ethical problems, but it should be noted that this racial discrimination takes no account of the level of infection in the country of departure or arrival.

- lastly, discrimination against homosexuals, with controversial measures concerning the closing-down of bathing and sauna establishments in the USA (particularly in San Francisco), which involve violation of privacy and of the right of association $(1,5,7,45,52$, $67,68,69)$.

Of course, all these discriminatory measures are much discussed, since they violate, at different levels, fundamental liberties and civil rights: freedom of movement, right to work, to education, to treatment, to privacy, etc. Discussions are carried on in many of the publications concerned in our study.

NON-RESPECT OF THE CONFIDENTIAL NATURE OF MEDICAL INFORMATION $(1,11,70,71,72,73,74,75$, $76,77,78,79,174)$

This involves a serious violation of the right to confidentiality. So far, most legislation specifically concerned with AIDS insists above all on the respect of that right (many states in the USA and several European countries).

- in Bavaria, however, the law provides for the information of sexual partners and the communication of information to the patient's doctor.

- in Sweden, legislation on this point has evolved in a very instructive way:

- in 1985, regulations intended to protect anonymity; - in April 1986, this protection of anonymity is restricted to 'certain circumstances';

- in December 1986, certain authorities or health personnel might be called on to give information concerning patients suffering from specified diseases. - in California, after the 1986 laws insisting on the respect of confidentiality, a series of laws approved in September 1987 define the conditions in which a breach of medical confidentiality is permitted, and allow the physician to inform the partner (or any person assumed to hold that status) in cases where seropositivity is confirmed.

- more recently (May 1988), firstly in Great Britain, the General Medical Council of the UK authorised physicians to advise the spouse or sexual partner in the case of a confirmed carrier; and, secondly, in the US (July 1988) the American Medical Association took the same position.

The patients' rights are threatened (1), notably the right to confidentiality and anonymity concerning health problems and the right to privacy. It is well known that non-respect of confidentiality in the case of AIDS can have considerable social, moral and financial consequences, and can trigger discriminatory reactions which may lead to tragedy. Finally, patients may refuse to consult a physician, if they have no confidence in his respect of confidentiality, and this attitude may have serious consequences for the spread of the disease.

However, many authors consider that AIDS represents such a serious threat that the importance lent to medical confidentiality is misplaced $(75,76,77)$. This position is based on the principle that AIDS is a public health emergency, and thus that certain civil liberties must give way in face of that emergency and of the imperative duty to protect the population. We will return to this question of medical confidentiality when dealing with protection of the individual.

APPLICATION OF THE PENAL CODE $(9,38,44,80,81,82$, 83)

The law, as it exists in the penal code, cannot apprehend the transmission of AIDS as an offence, because the terminological differences between carelessness, negligence, premeditation, intentional crime, etc, render it difficult to classify the transmission of a disease. Besides the difficulties of terminology, there is also the impossibility of establishing proof. The question has been raised of a special law relative to AIDS-transmission: the aim would be to encourage potential transmitters to warn their partners and to protect themselves. Such a law would penalise only those who did not comply with these two conditions. Since it interferes with individual sexual life, such a law could become an instrument for the persecution of certain groups.

In certain states of the USA and in certain European countries, drug addiction, prostitution and even certain sexual acts [(82) laws on sodomy] are covered by certain laws, and it is easy, under this pretext, to apply the penal code to AIDS.

In Bavaria, the intentional or negligent transmission 
of AIDS is covered by the penal code. Sweden has gone so far only as to prohibit prostitution by confirmed carriers; the same law applies in Nevada, while in Florida we find legislation which bluntly forbids confirmed carriers to have sexual intercourse (the same law holds in Louisiana and in Minnesota, although in less brutal terms).

SCREENING $(2,3,5,11,13,38,46,72,84,85,86,87,88,89$, $90,91,92,93,94,95,96,97,98,99,100,101,102,103,104$, $105,106,107,108,109,110,111,112,113,114)$

To be justified, screening must correspond to certain criteria of suitability, usefulness, acceptibility etc as defined by the epidemiologist. In the case of AIDS, a number of points can be discussed: essentially the fact that there exists at present no vaccine, nor any safe and effective pre-clinical treatment (though this may be changing), and that the statistics of infection remain very low in the general population. These facts imply that general screening cannot be very useful and would give rise to a considerable number of 'false positives' (mistaken positive tests). Many authors are thus led to regard general screening as unjustified: if it is compulsory for all, it raises major ethical problems; if it is voluntary, it is inefficient, even from the point of view of epidemiological research $(13,93)$.

Screening of target-groups has therefore been suggested: this would involve people associated with known risk factors: prostitution, homosexuality, intravenous drug addiction. We have underlined the markedly discriminatory character of such screening, which raises acute problems concerning confidentiality and anonymity (38). Alternatively people could be screened in particular circumstances such as blood donation, pregnancy, hospitalisation. Screening in prisons $(84,95)$ is based primarily on circumstances, though convicts can be regarded as a risk-group because of prison conditions (for example promiscuity and drug taking).

A rapid check of international legislation on screening shows that no country proposes to practise general screening of the whole population. The European Community, in the conclusions of the Council of Health Ministers held on May 15 1987, emphasises 'the inefficiency as a means of prevention of any recourse to a policy of systematic and compulsory screening, in particular in health controls at frontiers' $(3,11)$. Systematic screening is invoked for risk-groups, sometimes called 'cases presumed to be infected' (Bavaria, Finland, Israel, Louisiana), or authorities invoke the notion of 'an imminent threat to public health' (Florida, Indiana, Minnesota, Nevada, Texas...). Or again, risk-groups are defined with some precision: for example, in the USSR, screening concerns, apart from foreigners, patients subject to polytransfusions, drug addicts, homosexuals and prostitutes. In Indiana and Nevada, compulsory screening is limited to convicted persons $(96,97)$.

Sweden and Florida recommend systematic screening of pregnant women (99). Texas imposes an
HIV-test on any person who is to undergo a medical operation liable to put the hospital staff at risk, while in France it is emphasised that systematic screening of hospital patients is 'impractical and involves a financial cost totally out of proportion with possible results'; systematic HIV-screening to protect hospital staff is said to be out of the question $(98,100)$.

Lastly, legislation concerns informed consent to screening: Massachusetts demands written consent in all cases, while other states (California, Colorado, Indiana) go the other way in defining cases in which informed consent can legitimately be regarded as unnecessary $(101,102)$.

All questions relative to screening of blood donors will be treated in another paragraph.

COMPULSORY NOTIFICATION AND REGISTRATION (42, $115,116,117,118)$

Fairly quickly, and in a number of countries, AIDS was classified on the list of illnesses requiring compulsory notification. In the articles studied, this does not seem to raise any particular problems, but a distinction should be made between countries which have made notification compulsory for AIDS patients (CDC definition) and those which have extended this obligation to seropositives. (For example: Norway introduced compulsory notification in 1983 for AIDS patients; in 1986 this obligation was extended to cover cases of confirmed presence of antibodies, and the declaration was conceived in such a way as to maintain the anonymity of persons concerned).

From the ethical point of view, since seropositive means potentially infectious, compulsory notification of a seropositive condition raises no more problems than the notification of the disease itself. In the USA, in Canada, and elsewhere, such notifications are often identified by name, but must of course remain confidential. In France, where infectious diseases are notified anonymously, debate has been raised more recently around the idea of a register, be it anonymous or not, but no mention of this debate was to be found in our articles.

PROTECTION OF BLOOD GIVEN FOR TRANSFUSION (2, $5,17,81,119,120,121,122,123,124,125,126,127,128$, 129,130 )

The importance of problems related to bloodtransfusions is demonstrated by the fact that they were $O$ among the first (with compulsory notification of infection) to be treated by new legislation concerning AIDS:

- as early as 1983 the Council of Europe, France and Greece, all recommended the refusal of blood donors presumed to be infected or belonging to risk-groups (and there was similar legislation for Austria in 1984 and for Spain in 1985).

- in 1985 systematic screening of donors appears in the legislation of $W$ Germany, Belgium, France, 
Luxemburg, Norway, and in the state of Washington. At present, such screening is systematic in the US and in European countries.

- several states specify that donors should be informed of the results: Arizona, Illinois, Oklahoma (there is the same specification in Venezuela), while others define the conditions of maintaining anonymity (for instance the State of Washington).

- in California and in Wisconsin, the law goes further in requiring the informed, written consent of the donors, specifying that they accept the screening and accept that the results will be communicated to them, while remaining strictly confidential.

- in Australia, as from 1985, provision was made to limit the liability of blood-banks, by inviting donors to sign a declaration specifying that they do not practise any high-risk activity. In the state of Tennessee a 1987 law specifies that it is forbidden for any confirmed seropositive to give or to try to give blood.

-in 1986 and 1987 certain laws were passed with a view to limiting the liability of blood-banks (Idaho, Mississipi, Montana, New Mexico, Dakota). These laws all boil down to the declaration that blood-giving is a 'service' and not an act of sale: the implicit guarantees attached to commercial products are therefore not applicable.

- lastly, in California, Dakota and Illinois, regulations have been adopted to allow 'directed' blood-giving, ie the receiver of the transfusion knows personally the blood donor.

In articles published in scientific reviews, the question is broached of the responsibility of blood-banks in cases of infection, and two levels of protection may be distinguished, one relating to the screening of donors, the other to the screening and/or treatment of blood.

So far as donors are concerned, exclusion may be advocated of donors belonging to risk-groups, identified by a questionnaire concerning their way of life and exclusion of those classed among paid professional donors (a common practice in the US), who are particularly likely to belong to certain riskgroups.

Some authors recommend the practice of autotransfusion when possible. Debate remains open on the question of 'directed' blood-transfusions. Bloodbanks might be accused, by a recipient infected by HIV, of failing to provide him with blood from a 'safe' donor known personally to him. It has yet to be demonstrated that such 'directed' transfusions improve safety, an argument rejected almost unanimously by blood-banks. The ethical problem raised by 'directed' transfusions is characterised by the fact that they involve the identification of the donor: anonymity is abandoned.

Measures concerning products injected: blood-banks must screen all blood given and, whenever possible, achieve viral inactivation in products to be injected: these points are unanimously accepted.
Several authors adopt the recommendations of the American Association of Blood Banks and of the American Association of Tissue Banks: blood and tissue-banks cannot be held responsible for harm resulting from transfusion, and can be attacked only for negligence or intentional fault. Indeed, transfusion should be considered as a 'service' and not as a product. Besides these recommendations, and with the intention of further limiting the liability of those involved in transfusions (blood-banks, hospitals and prescribing doctors), it has been suggested that the receiver should sign a written consent specifying that he has been warned of the risks inherent in transfusions.

In publications concerning transfusions, two other points are also raised:

- confidentiality;

- the duty of the donor to give accurate information.

These measures being intended to protect the individual, they will not be treated in this section. Nevertheless, earlier in this section, we alluded to measures intended to protect both transfusionrecipients and blood-donors, which relate to these issues.

RESEARCH ON DRUGS AND VACCINES (131,132,133, $134,135,136,137,138,139,140,141,142,143,144,145$, $146,147)$

Apart from the usual ethical considerations which apply to all medical activities (voluntary choice, informed consent, protection of patients suffering from diminished autonomy, maximum benefit for the patient, etc), the problem with a very serious illness like AIDS is that it may seem immoral to deprive the patients of a treatment which may be beneficial to him (126).

The whole research structure of therapy versus placebo is called into question, and traditional conflicts are exacerbated: some authors consider that as soon as a drug has shown 'probable' efficiency, the trial should be interrupted and the drug distributed, in order to give hope to all patients. Others maintain that random double-blind trials are the only sure means of distinguishing between the real efficacy of a drug and effects due to chance. These authors insist on the serious misapprehensions, sometimes irremediable, based on trials terminated too quickly and without respecting a strict protocol.

Concerning vaccines, the problem of therapeutic trials is rendered more complex in several ways:

The mode of transmission (blood or sexual contact) raises the problem of the choice of subjects to be admitted to the trial. If a low-risk population is chosen, the immunological reaction can be measured, as well as possible side-effects, but no conclusion can be drawn as to the protective value of the vaccine. With subjects belonging to a risk-group, difficulties are enhanced: 
the latent period between infection and seroconversion (seropositive reaction) makes it essential to be absolutely certain that the subject to be vaccinated is not already infected, - partly to avoid implicating the vaccine as responsible for a previous infection, and partly because of the danger which a live vaccine represents for an organism with weakened immune defences. However, there seem to be no simple, efficient and morally acceptable means of distinguishing between a non-infected risk-subject and an infected risk-subject before sero-conversion.

Moreover, if the researcher has chosen a risk-group, his scientific interest is best served if the subjects do not adopt special measures to minimise the risk of infection. However, it would be ethically irresponsible for a researcher to obtain consent to a test-vaccine without informing the subjects of the need to take precautions. And each time the subject returns to pursue his tests, the researcher's duty is to warn him of the urgent need to protect himself. It is not clear how this problem can be solved, but the solution is obviously not the silence of the researcher, leaving his subject in ignorance for fear he should spoil the test. As the volunteers inevitably become more sensitive to the risks and more conscious of the means of protection, this situation can give rise to erroneous results or false hopes as to the efficiency of a drug.

Other legal problems concern the manufacture of a vaccine. How are companies to be encouraged to launch into the long and hazardous enterprise of finding an anti-HIV vaccine, when we do not even know if such a vaccine will be accepted by the public? Since pharmaceutical firms define their projects in terms of financial profit and loss, a serious economic obstacle arises.

Further, how can the liability of manufacturers be limited in case of accident? We have seen that American law, which renders manufacturers totally liable for their products, has been attenuated in order to limit the liability of blood-banks in case of accidental contamination.

In the case of vaccines, plans to limit liability are now under study, particularly in California (5): since the vaccine is considered to be 'inevitably dangerous', this liability is more or less covered by state authorities, and these measures are accompanied by financial aid to research and by the guarantee that unsold vaccines will be bought back by the state.

Lastly, we find ethical problems related to the distribution of vaccine.

Debate is raised on the subject of anti-HIV vaccination because of the mode of transmission of the illness, which is much more selective than diseases such as smallpox, polio, tetanus etc.

Who is to be vaccinated? Should vaccination be compulsory or voluntary? Should the whole population not yet infected be vaccinated? We thus meet again all the ethical problems linked to compulsory screening. Since vaccination is not without risk, can it be made compulsory for people whose behaviour does not expose them to the risk of infection? Or should vaccination be restricted to riskgroups, with the concomitant discrimination involved in such an option?

Or, lastly, should vaccination be given on a voluntary basis, with the hope that sufficient protection will be obtained for the population? If a voluntary system were to be established, it is feared that many members of risk-groups (homosexuals, persons with many sexual partners, drug addicts) would be reluctant to identify themselves as such by reporting to a vaccination centre, unless a guarantee of absolute anonymity were given.

In the US compulsory vaccination is being considered for homosexuals, drug addicts and Haïtians; vaccination would be voluntary for haemophiliacs. But such a system would miss subjects who do not belong to these groups and who are likely to be contaminated by AIDS.

Let us conclude this reflection on drugs and vaccines by emphasising the role of the media, which is particularly important in the AIDS context: the media are always on the look-out for sensational news, and thus create false hopes of miracle-drugs.

INFORMATION AND EDUCATION $(5,20,64,68,148,149$, $150,151)$

We now come to consider the least coercive measures of social protection.

Particularly in the US (5) educational programmes have been established. At the school level (California, North Carolina, Illinois, Nevada, Rhode Island), there is occasionally the proviso that parental or tutorial permission is necessary. In this context we sometimes find positions which might be considered amusing or puritanical: for instance, in Rhode Island the law requires instructors to insist on 'the fact that abstinence from any sexual relations is the best means of prevention'; and in Illinois the law 'has the effect of introducing into the pedagogical program of all schools in the state the lesson of abstinence before marriage'.

At the level of general public education programmes are to be established in Indiana and in Pennsylvania, the latter specifying that the public will be given 'accurate and concrete information about AIDS and the risks inherent in activities of everyday life'. Information and education have a double objective: to warn of the risks, to define the modes of transmission and the means of protection; but also to reduce perception of these risks to their true proportions, to allay fears which provoke discriminatory reactions and to fight against misinformation spread by the gutterpress (105). It is undoubtedly essential that certain basic messages be received, for instance that AIDS is not transmitted by ordinary contact. This message is particularly important for parents of pupils in schools attended by HIV-positive haemophiliac children.

Some authors (150) maintain that all information is desirable, even that regarded by others as indecent and 
shocking (for example information on behaviour of the homosexual community). They maintain that such information raises no moral problems, but that ethical questions should be asked when efforts are made to restrict such behaviour, discouraging, for example, repeated changes of partner: 'How far can society go in imposing its moral restrictions on a group of individuals?'

Lastly, a polemical debate has arisen concerning the reliability of condoms (148), the authors emphasising that the 'safe sex' campaign is based on a lie and is therefore unethical.

\section{II - Measures intended to protect the individual}

RIGHTS OF THE PATIENT $(3,10,11,152,153,154,155$, 156,157)

The fundamental rights of the patient are three in number:

- a right to confidentiality;

- a right to information;

- a right to treatment.

Right to confidentiality $(1,2,5,7,11,70,71,72,73,74,75$, $76,77,158,159,160,161,162,163,164,165,166,167$, $168,169,170,171,172,173,174,175,176,177)$

Confidentiality is not only a principle of medical ethics, but also a principle covered by the penal code. Medical confidentiality aims to protect certain articles of the Universal Declaration of Human Rights, in particular respect of privacy and the rejection of discrimination.

However, as soon as AIDS appeared, the principle of medical confidentiality was hotly debated. In our first section we saw the arguments of those who recommend a breach of medical confidentiality, with the aim of protecting society.

For those who defend the rights of the individual, medical confidentiality ensures respect of the patient's dignity. It protects his privacy and his health, enabling him to undergo treatment with a confidence which encourages him to reveal his problems and to discuss them without inhibition, since he has no fear of betrayal of that confidence. It is indeed well known that a dramatic social stigma is attached to the diagnosis of AIDS, because of the risks of contagion and the concomitant discrimination.

Moreover, medical confidentiality is at present the safest means of protecting public health, since the physician who has his patient's confidence can fully play his preventive role, encouraging the patient to warn his relations and to adopt a responsible sexual behaviour. Some authors extend the demands of confidentiality to the refusal to share confidence with other physicians or with nursing staff, which seems to be an extreme position to take and, indeed, very difficult to respect.

On the other hand, since we are concerned here with the rights of the individual, the breach of medical confidentiality contributes to the protection of those in contact with the patient: it may protect their right to be warned and informed so as to be able to take appropriate prophylactic measures. It is this conflict between the rights of the patients and the rights of those in contact with him that is at the heart of the whole discussion.

While many countries and states insist in their legislation on the confidential nature of medical information (and sometimes on the protection of anonymity), we have observed that restrictions of that confidentiality have been introduced over the years (California, Nevada, Kentucky, Texas, Sweden, Great Britain), with provision for information of sexual partners, of drug addicts sharing syringes, and of nursing staff. It seems that this tendency towards breach of confidentiality may gain ground in the coming years.

Right to information $(1,3,68,131,153,178,179,180,181$, $182,183,184,185,186,187,188$ )

It is important that the patient has information at three levels: information about screening (informed consent); information about the disease, and information about therapeutic decisions.

The basic principle being the respect of the individual, it appears that a patient should not be screened without his consent, and this entails authorising only voluntary screening, this being a free decision of the subject who accepts such screening fully conscious of the risks. This is the position adopted by the Working Committee on AIDS at the European Council. The fact that certain tests have become part of routine examinations (syphilis test in pre-marital and pre-natal examinations) tends to suggest that consent is implicit. It may indeed be so whenever a positive test entails only the application of an efficient treatment. However, because of the prognosis and the lethal outcome of AIDS, how can a patient be informed of seropositivity if he has not previously given his explicit consent to the test?

Information about his illness is also part of the patient's rights. The problem of whether to warn the patient of the diagnosis is apprehended differently in different countries. In France, for instance, this decision is left to the physician; in the US systematic communication of information to the patient is often due to fear of court proceedings in case of mistaken diagnosis. Given the seriousness of the diagnosis in the case of AIDS, information may give rise to negative psychological effects (depression, suicide). However, it appears difficult to refuse information to the patient, when preventive measures to protect those in contact with him depend on that information. One of the recommendations of the American Medical Association is that the physician should give his patient information, education and counsel, so that he may become conscious that, as well as rights, he also has duties implied by respect for the non-infected population.

As far as therapeutic decisions are concerned, many 
authors consider that the informed consent of the patient is the indispensable guarantee of the respect due to all human persons. As long as the patient is in a condition to receive information and as long as he has confidence in the medical staff, his consent is practically implicit. However, the patient has the right to interrupt his treatment at any moment, provided he be considered 'capable of understanding' the consequences of his decision and after he has been given 'clear' information. One problem is that some patients suffering from AIDS become incapable of sharing therapeutic decisions because of grave disorders of the central nervous system. With whom should the continued treatment then be discussed? The difficulty is often enhanced by the patient's way of life which creates a delicate situation: he is often rejected by his family, and thus no relatives are there to take decisions. Can the physician then accept discussion with the patient's sexual partners or his close friends, when they have no legal right to represent him?

No author can take a position on this point and no rule can be established, unless the patient has made clear his wishes while still competent, and some centres promote active discussion of these issues at an early stage of the illness so that patients' views can be properly ascertained. Many articles touch on these problems in discussing the right to refuse treatment which they regard as 'an unnecesary prolongation of therapy', or again in discussing the right to suicide when the patient reaches the terminal phase.

Right to treatment $(109,117,153,175,177,189,190,191$, $192,193,194,195,196,197,198,199,200,201,202,203$, $204,205,206,207,208,209,210,211,212,213,214,215$, 216,217)

Patients have always had the right to treatment. This is a fundamental principle in medical care which applies even when there is risk to the medical staff.

In the case of AIDS, reactions of fear and rejection are such that cases have arisen, above all in the US, where doctors and nursing staff have refused to treat patients. This situation became so serious that the (UK) Royal College of Nursing felt obliged to demand in 1986 that disciplinary measures be taken against any nurse refusing to treat patients infected by HIV. In 1987 the (UK) General Medical Council insisted on the following points: 'It is unethical for a doctor to refuse to treat or examine a patient for the sole reason that the patient's condition may put the doctor at personal risk. It is unethical for a doctor to refuse to treat a disease under the pretext (moral judgement) that the patient's way of life brought on that disease'.

The American College of Physicians and the Infectious Disease Society of America have adopted an identical position, declaring that 'it is unethical not to give a sick or dying patient appropriate treatment, whatever the reason'. On the other hand, the American Medical Association has taken a more ambiguous position, specifying that since not everyone is emotionally capable of treating an AIDS patient, it is up to practitioners to find means of respecting the American Medical Association regulations (146).

Authors emphasise that the medical professions have always been exposed to danger, and that the readiness of those professions to treat patients must not depend on the degree of the danger. Ethics oblige the doctor to treat the patient, even at the risk of his own life.

To avoid a situation in which hospital staff refuse to treat AIDS patients for fear of contagion, it is indispensable that time be devoted to the information and education of that staff, and that the staff be equipped with the means to apply the appropriate measures of protection: to be well acquainted with the risks, not to exaggerate nor to minimise them, to know and to know how to apply the indispensable means of stopping transmission of AIDS. The precautions prophylactic recommendations of the CDC (144) - are moreover the same as for other diseases (B hepatitis). This implies that there is not necessarily any need to inform the staff that a patient has AIDS. All patients represent a risk: contamination can be brought about by professional fault, and does not necessarily involve the liability of the hospital, provided appropriate training has been given and the means supplied to apply prophylactic measures.

FUNDAMENTAL RIGHTS OF THE INDIVIDUAL (40,149, $218,219,220,221,222,223,224,225,226,227,228,229$, 230,231,232)

For the seropositive or AIDS patient, besides the fundamental rights of the patient (right to confidentiality, to information and to treatment), there exist also the rights of the individual which are not inscribed in the codes of medical ethics, but in the Declaration of Human Rights and in the common law of each country.

These are rights put at risk by all the measures destined to protect society that we enumerated in a previous section of this article: rights of movement, non-discrimination, work, education, privacy, 'free choice', association, etc.

In the framework of discrimination which is always present in the AIDS context the respect of these rights requires constant vigilance. We have observed that as the progression of the disease becomes more alarming, these rights are more and more seriously called into question.

However, besides patients and seropositives, the rights of certain other people are individually threatened by the AIDS epidemic.

Thus the rights of those in contact with seropositive individuals (sexual partners or people sharing syringes) may need upholding: we have seen that certain governments have proposed and applied breach of medical confidentiality, and that this measure, which represents an extreme prejudice to the patient, contributes nevertheless to the protection of those in contact with him (right to be informed of risks to which 
they are exposed). In the same way, the application of the penal code to subjects who spread HIV contributes, as far as his contacts are concerned, to the respect of the 'principle of independence'.

Another group whose rights may be threatened are members of the medical staff $(20,21,22,23,24,25,26,27$, $28,219,229,230,231,232)$ : for instance, compulsory screening for all patients about to undergo a surgical operation or endoscopical examination, contributes, as far as the medical staff is concerned, to the respect of their right to safe working conditions. Recently in Norway and Denmark, the inclusion of AIDS in the category of work-accidents or professional diseases (for such staff) provides them with social security coverage.

Recipients of blood-transfusions, transplants or artificial insemination also have a right to safe treatment, which implies the systematic screening of donors.

These various conflicting rights of different groups of individuals give a good idea of the complexity of the ethical problems raised in the AIDS context. We have tried to treat these ethical problems as thoroughly as possible.

\section{Conclusion}

In the course of this study we collected sharply differing opinions which can be summed up as follows: society must be protected, the individual must be respected. Were privacy no longer respected, the treatment centres now established would be deserted, and the consequent failure of all our efforts to stop this world-wide epidemic could mean the end of our society.

This blunt résumé leads us to offer a personal conclusion: the conflict may be interpreted in two ways:

We live in a world of conflict, in which each actor defines the limits of his opponent's territory; balance is always unstable, favouring first one and then the other; we go from one extreme to another, from extreme severity to extreme laxism, each extreme tending to reduce (or provoke) the other.

However, this image of two opposed vectors to be subtracted one from the other does not seem to us to constitute a satisfactory conclusion as to the relations between the rights of the individual and the rights of society. We would prefer an architectural image: individual rights are the indispensable buttress of our society. Certainly, AIDS is not the keystone of our society, but it is the metaphor of our contradictions.

C Manuel - Chemist. Specialised Diploma in Statistics and Epidemiology (Paris, CESAM-STEP), Assistant Professor. Laboratoire de Santé Publique, Faculté de Médecine, 27, Bd fean Moulin 13385 Marseille Cédex 5, France. Tél: (33) 91921194 . P Enel-MD. Specialised Diploma (CES) in Public Health (Marseille), Masters
Degree in Public Health (Montréal), Contractual Hospital Consultant. Laboratoire de Santé Publique, Faculté de Médecine, 27, Bd Fean Moulin 13385 Marseille Cédex 5, France. Tél: (33) $91921194 . \mathcal{F}$ Charrel - MD. Graduate in Science (Marseille), Specialised Diploma (CES) in Public Health (Marseille), Assistant Professor. Laboratoire de Santé Publique, Faculté de Mèdecine, 27, Bd fean Moulin 13385 Marseille Cédex 5, France. Tél: (33) $91921194 . D$ Reviron - MD. Postgraduate Degree (DEA) in Immunology and Blood Transfusion (Paris), Specialised Diploma (DES) in Public Health (Marseille), Resident Hospital Consultant. Centre de Transfusion Sanguine, 147 Bd Baille, 13005 Marseille, France. M P Larher MD. Postgraduate Degree (DEA) in Health Economics (Lyon) and Specialised Diploma (DES) in Public Health (Marseille), Resident Hospital Consultant. Laboratoire de Santé Publique, Faculté de Médecine, 27, Bd fean Moulin 13385 Marseille Cédex 5, France. Tél: (33) 9192 11 94. X Thirion - MD. Postgraduate Degree (DEA) in Health Economics (Lyon), Assistant Hospital Consultant. Laboratoire de Santé Publique, Faculté de Médecine, 27, Bd Fean Moulin 13385 Marseille Cédex 5, France. Tél: (33) 919211 94. F L Sanmarco - MD. Specialised Diploma (CES) in Public Health (Marseille) Professor in Public Health. Laboratoire de Santé Publique, Faculté de Médecine, 27, Bd fean Moulin 13385 Marseille Cédex 5, France. Tél: (33) 91921194.

\section{References}

(1) Kelly K. AIDS and ethics. An overview. General hospital psychiatry 1987; 9:331-340.

(2) Gostin L O, Curran W J, Clark M E. The case against compulsory casefinding in controlling AIDS: testing, screening and reporting. American journal of law and medicine 1987; 12:753.

(3) American Medical Association. Prevention and control of AIDS. An interim report. Fournal of the Tennessee Medical Association 1987; 80:543-549.

(4) Rogers H L Jr. The implications of AIDS [editorial]. Fournal of the Medical Association of Georgia 1987; 76:620-621.

(5) WHO. Tabular information on legal instruments dealing with AIDS and HIV infection, Jun 1988/Dec 1988/May 1989.

(6) Curran W J. The impact of legal issues on the practice of infectious disease: national survey of AIDS legislation. Bulletin of the New York Academy of Medicine 1987; 63: 569-581.

(7) Anonymous. The constitutional rights of AIDS carriers. Harvard law review 1986; 99:1274-1292.

(8) Mills M, Wofsy C B, Mills J. The acquired immunodeficiency syndrome. Infection control and public health law. New England journal of medicine 1986; 314:931-936.

(9) Macklin R. Predicting dangerousness and the public health response to AIDS. Hastings Center report 1986; 16 (suppl): 1623.

(10) American Psychological Association. Statement on ethical issues in psychological research on AIDS. IRB: a review of human subjects research 1986; 8:8-10.

(11) American College of Physicians, Health and Public Policy Committee, Infectious Diseases Society of America. Acquired immunodeficiency syndrome (position paper). Annals of internal medicine 1986; 104:575-581.

(12) Long D L. AIDS - fighting the economic epidemic. Nursing management 1987; 18:66-71.

(13) Kirby M D. AIDS legislation - turning up the heat. Fournal of medical ethics 1986; 12:187-194.

(14) Edelman R. From the National Institutes of Health. Summary of the National Institutes of Health research workshop on the 
epidemiology of the Acquired Immunodeficiency Syndrome (AIDS). Fournal of infectious diseases 1984; 150:295-303.

(15) Birchfield J L. AIDS: the legal aspects of a disease. Medicine and law $1987 ; 6: 407-426$.

(16) Merritt D J. The constitutional balance between health and liberty. Hastings Center report 1986; 16 (suppl):2-10.

(17) Coil J H. Legal issues involving AIDS. Fournal of the Medical Association of Georgia 1987; 76:64-68.

(18) Britton S. Psychosocial aspects of HTLV-III infections. Scandinavian journal of social medicine 1986; 14:211-212.

(19) Eisenberg L. The genesis of fear: AIDS and the public's response to science. Law, medicine and health care 1986; 14:243249.

(20) Ostrow D G, Gayle T C. Psychosocial and ethical issues of AIDS health care programs. QRB: quality review bulletin 1986; $12: 284-289 ; 292-294$.

(21) Anonymous. AIDS in Europe. AIDS - forschung 1986; 1:361399.

(22) Lewis H E. Acquired immunodeficiency syndrome! State legislative activity. Fournal of the American Medical Association 1987; 258:2410-2414.

(23) Falk T C. AIDS public health law. foumal of legal medicine 1988; 9:529-546.

(24) Furrow B R. AIDS: designing a balanced legislative response. Delaware medical journal 1988; 60:51-59.

(25) Rentchnik P. Le SIDA aux Etats Unis. Médecine et hygiéñe 1988; 46:1464-1473.

(26) Keeling R P. General statement on institutional response to AIDS, revised January 1988. Task force on the Acquired Immunodeficiency Syndrome (AIDS). Fournal of American College of Health 1988; 37:121-125.

(27) Anonymous. Ethical issues involved in the growing AIDS crisis. Council on Ethical and Judicial Affairs. Fournal of the American Medical Association 1988; 259:1360-1361.

(28) Connor S S. AIDS: social, legal, and ethical issues of the 'third epidemic'. Bulletin of the Pan American Health Organisation 1989; 23:95-107.

(29) Judson F N. What do we really know about AIDS control? American journal of public health 1989; 79:878-882.

(30) Ankrah E M. AIDS: methodological problems in studying its prevention and spread. Social science and medicine 1989; 29:265276.

(31) Hirsh H L. AIDS and the law. A summary and conclusion. fournal of legal medicine 1989; 10:169-210.

(32) Ross M W. Psychosocial ethical aspects of AIDS. Fournal of medical ethics $1989 ; 15: 74-81$.

(33) Orr A. Legal AIDS: implications of AIDS and HIV for British and American law. Fournal of medical ethics 1989; 15:61-67.

(34) Krazsnik A, Bjoerner J, Christensen B W. Community and individual considerations in legislation and test policy regarding HIV-infection in the Nordic countries: a cross national comparative study. Social science and medicine 1989; 29:577584.

(35) Ford N L, Quam M D. AIDS quarantine. The legal and practical implications. Fournal of legal medicine 1987; 8:353-396.

(36) Petit C. California to vote on AIDS proposition. Science 1986; 234:277-278.

(37) Anonymous. Detaining patients with AIDS. British medical journal 1985; 291:1102.

(38) Porter R. History says no to the policeman's response to AIDS [editorial]. British medical journal 1986; 293:1589-1590.

(39) Fenton T W. Practical problems in the management of AIDSrelated psychiatric disorder. Foumal of the Royal Society of Medicine 1987; 80:271-274.

(40) Restak R. Worry about survival of society first; then AIDS victims' rights. Washington Post 1985 Sept 8: $\mathrm{Cl}, \mathrm{C} 4$

(41) Sidel V W. The prevention of AIDS. New York State fournal of Medicine 1987; 87:259-260.

(42) Gostin L, Curran W J. Legal control measures for AIDS: reporting requirements, surveillance, quarantine, and regulation of public meeting places. American journal of public health 1987; 77:214-218.

(43) Palca J. AIDS in California. Proposition causes PANIC. Nature 1986; 323:384.

(44) Gostin L, Curran W J. The limits of compulsion in controlling
AIDS. Hastings Center report 1986; 16 (suppl): 24-29.

(45) Burris S. Fear itself: AIDS, herpes and public health decisions. Yale law and policy review $1985 ; 3: 479-518$.

(46) Ory H W, Koplan J P, Allen J R. Assessment of screening as a preventive technology: the example of HTLV-III/LAV antibody testing. Israel journal of medical sciences 1986; 22:524 528.

(47) Crumpler D C, Carey M. Employment considerations of AIDS in dental institutions. Fournal of dental education 1987; 51:465470.

(48) Druhot D M. Immigration laws excluding aliens on the basis of health. A reassessment after AIDS. Fournal of legal medicine 1986; 7:85-112.

(49) Landesman S H, Ginzburg H M, Weiss S H. The AIDS epidemic. New England journal of medicine 1985; 312:521-525.

(50) Parmet W E. AIDS and the limits of discrimination law. Law, medicine and health care 1987; 15:61-72.

(51) Nelson J B. Responding to, learning from, AIDS. Christianity and crisis 1986; 46:176-181.

(52) Velimirovic B. Social, ethical, psychological and financial dilemmas of AIDS: implications for health policy. AIDS forschung 1986; 1:253-258; 307-317.

(53) Thomas D K. The legal status of AIDS at the workplace in the United States. Medical anthropology 1989; 10:193-201.

(54) King M M. AIDS: employer and employee rights. foumal of legal medicine 1988; 9:587-599.

(55) Wilson B L, Wingo K L. AIDS in the workplace. Handicap discrimination laws and related statutes. Fournal of legal medicine $1988 ; 9: 573-585$

(56) Anonymous. AIDS and the workplace. Lancet 1988; 2:841-842.

(57) MacFarlane M A. Equal opportunities: protecting the rights of AIDS-linked children in the classroom. American journal of law and medicine $1989 ; 14: 377-430$.

(58) Stratton W T. The legal aspects of AIDS. Kansas medicine 1986; $87: 82-86$

(59) Logan M K. Legal, ethical issues for dentists. Fournal of the American Dental Association 1987; 115:402.

(60) Goerth C R. Firing employees who have AIDS brings on new round of legal action. Occupational health and safety 1985; 54:28.

(61) Nelkin D, Hilgartner S. Disputed dimensions of risk: a public school controversy over AIDS. Milbank quarterly 1986; 64 (suppl 1): 118-142.

(62) Linn R. When an AIDS child enters the classroom: moralpsychological research questions. Psychological reports 1987; 61:191-197.

(63) Rubinstein A. Schooling for children with acquired immune deficiency syndrome. Fournal of pediatrics 1986; 109:242-244.

(64) Jager H. Ethical issues in AIDS. AIDS - forschung 1986; 1:513514.

(65) Black J L. AIDS: preschool and school issues. Fournal of school health 1986; 56:93-95.

(66) Etheredge L. Ethics and the new insurance market. Inquiry $1986 ; 23: 308-315$.

(67) Mohr R D. AIDS, gays, and state coercion. Bioethics 1987; $1: 35-50$.

(68) Silverman M F, Silverman D B. AIDS and the threat to public health. Hastings Center report 1985; 15 (suppl): 19-22.

(69) Rabin J A. The AIDS epidemic and gay bathhouses: a constitutional analysis. Fournal of health politics, policy and law 1986; 10:729-747.

(70) Healey J M. Confidentiality and AIDS. Connecticut medicine 1987; 51:689.

(71) Grote C A Jr. MASA's tentative AIDS policy. Alabama medicine $1987 ; 57: 11-12$

(72) Boyd K M. The moral challenge of AIDS. Fournal of the Royal Society of Medicine 1987; 80:281-283.

(73) Welsby P D. Personal view: HTLV-III testing without consent British medical journal 1986; 292:954.

(74) Kleinman I. Transmission of human immunodeficiency virus: ethical considerations and practical recommendations. Canadian Medical Association journal 1987; 137:597-599.

(75) Levenson J L. Position paper on acquired immunodeficiency syndrome [letter]. Annals of internal medicine 1986; 105:466467.

(76) Mc Clatchey W M. AIDS. A physician responds: confidentiality 
may kill. Fournal of Christian nursing 1987; 4:8-9.

(77) Swinbanks D. AIDS becomes a notifiable disease in Japan despite protests. Nature 1987; 326:232.

(78) Potterat J J, Spencer N E, Woodhouse D E, Muth J B. Partner notification in the control of human immunodeficiency virus infection. American journal of public health. 1989; 79:874-876.

(79) Zonana H. Warning third parties at risk of AIDS: APA's policy is a reasonable approach. Hospital and community psychiatry 1989 ; 40:162-164.

(80) Field M A, Sullivan K M. AIDS and the criminal law. Law, medicine and health care $1987 ; 15: 46-60$.

(81) Hermann D H. Liability related to diagnosis and transmission of AIDS. Law, medicine and health care 1987; 15:36-45.

(82) Beauchamp D E. Morality and the health of the body politic. Hastings Center report 1986; 16 (suppl): 30-36.

(83) Sinkfield R H, Houser T L. AIDS and the criminal justice system. Fournal of legal medicine 1989; 10:103-125.

(84) Gostin L, Curran W J. AIDS screening, confidentiality, and the duty to warn. American joumal of public health 1987; 77:361-365.

(85) Bayer R, Levine C, Wolf S M. HIV antibody screening. An ethical framework for evaluating proposed programs. Fournal of the American Medical Association 1986; 256:1768-1774.

(86) Kocher B. AIDS: fantasies and realities. Krankenpflege 1987; 80:72-73.

(87) Hopkins D R. Public health measures for prevention and control of AIDS. Public health reports 1987; 102:463-467.

(88) Miller D, Jeffries D J, Green J, Harris J R, Pinching A J. HTLV-III: should testing ever be routine? British medical journal 1986; 292:941-943.

(89) State Medical Society of Wisconsin. Policy recommendations on AIDS and HIV infection. Wisconsin medical journal 1987; 86:1518.

(90) White J P. Mandatory AIDS testing. Testing disruptive, not cost effective. West Virginia medical journal 1987; 83:492.

(91) Stevenson M M. Mandatory AIDS testing - step in the wrong direction. West Virgina medical joumal 1987; 83:491.

(92) Apelgren K N. AIDS approach criticized [letter]. West Virginia medical journal 1987; 83:439.

(93) Mills J. What can be done against the further spread of AIDS? Infection 1987; 15:160-161.

(94) AIDS: risks and responsibilities [editorial]. Washington Post 1985 Aug 14: A22.

(95) Demontigny L H. Mandatory testing needed [letter]. West Virginia medical journal 1987; 83:556.

(96) Mohammed I, Chikwem J O, Harry T O, Nasidi A. AIDS: a faltering step [letter]. British medical journal 1987; 295:392.

(97) Gillon R. Testing for HIV without permission. British medical joumal 1987; 294:821-823.

(98) Rezet B E. Mandatory AIDS testing. False positive ELISA reactions will predominate. West Virginia medical journal 1987; 83:492-493.

(99) Cleary P D, Barry M J, Mayer K H, Brandt A M, Gostin L, Fineberg H V. Compulsory premarital screening for the human immunodeficiency virus. Technical and public health considerations. Fournal of the American Medical Association 1987; 258:1757-1762.

(100) Burda D. AIDS law in CA binds hospitals. Hospitals 1987; 61:50.

(101) Morris C A. AIDS counselling and informed consent [letter]. British medical journal 1987; 294:839.

(102) Wyatt D, Payne M, Ingram L, Qinley P. AIDS: legal and ethical concerns for the clinical laboratory. Fournal of medical technology 1987; 4:108-111.

(103) Perry S W, Markowitz J C. Counselling for HIV testing. Hospital and community psychiatry 1988; 39:731-739.

(104) Stimmel B. To test or not to test: the value of routine testing for antibodies to the human immunodeficiency virus (HIV). Advances in alcohol and substance abuse 1987; 7:21-28.

(105) Mohr R D. Policy, ritual, purity: gays and mandatory AIDS testing. Law, medicine and health care 1988; 15:178-185.

(106) Krim M. Mass screening, civil liberties, and the public health. Introductory remarks. Annals of the New York Academy of Sciences 1988; 530:154-156.

(107) Weiss R, Thier S O. HIV testing is the answer, what's the question? New England journal of medicine 1988; 319:1010-
1012.

(108) Bayer R. Screening and AIDS: the limits of coercive intervention. Annals of the New York Academy of Sciences 1988; 530:159-162.

(109) Dickman S. Mandatory AIDS tests on basis 'of slight suspicion' in Bavaria. Nature 1988; 333:585.

(110) Clark $H$ W, Washburn $P$. Testing for human immunodeficiency virus in substance abuse treatment. Foumal of psychoactive drugs $1988 ; 20: 203-211$.

(111) Hagen M D, Meyer K B, Pauker S G. Routine preoperative screening for HIV. Does the risk to the surgeon outweigh the risk to the patient? Fournal of the American Medical Association 1988; 259:1357-1359.

(112) Meyer K B, Pauker S G. Screening for HIV: can we afford the false positive rate? New England journal of medicine 1987; 317:238-241.

(113) Anonymous. Criteria for HIV screening programs. Bulletin of the Pan American Health Organisation. Washington: 1989; 23:176-182.

(114) Frierson R L, Lippmann S B. What about mandatory AIDS testing? Journal of the Kentucky Medical Association 1989; 87:6671.

(115) Fox D M. From TB to AIDS: value conflicts in reporting disease. Hastings Center report 1986; 16 (suppl): 11-16.

(116) Glynn A A. Should AIDS be notifiable? [letter]. Lancet 1987; 2:750.

(117) Knight S. AIDS in Louisiana. Louisiana legislation. Fournal of the Louisiana State Medical Society 1987; 139:89-91.

(118) Ohi G, Terao H, Hasegawa T, et al. Notification of HIV carriers: possible effect on uptake of AIDS testing. Lancet 1988; 8617:947-949.

(119) Lipton K S. Blood donor services and liability issues relating to acquired immune deficiency syndrome. Fournal of legal medicine 1986; 7:131-186.

(120) Miller P J, O'Connell J, Leipold A, Wenzel R P. Potential liability for transfusion-associated AIDS. Fournal of the American Medical Association 1985; 253:3419-3424.

(121) Aronson D L. Regulation and licensing of US plasma products: response to AIDS. Developments in biological standardization 1987; 67:215-220.

(122) Curran W J. AIDS research and 'the window of opportunity'. New England joumal of medicine 1985; 312:903-904.

(123) Anonymous. Potential liability for transfusion-associated AIDS [letter]. Foumal of the Americal Medical Association 1986; 255:195-197.

(124) Burda D. Hospital not liable for AIDS from blood transfusion. Hospitals 1987;61:60.

(125) Bove J R, Dodd R Y, Miller W V, Sandler S G. How should we handle the ethical questions regarding information to donors and patients and the practical implications regarding deferral of donors and handling of donated blood in the event of introducing a screening test for HTLV-III as in order to prevent transmission of AIDS by blood transfusion? (clinical conference). Vox sanguinis 1985; 49:234-239.

(126) Bhatia H M. Acquired immuno-deficiency syndrome (AIDS). Its impact on blood transfusion services. Indian journal of medical sciences $1987 ; 41: 88-91$.

(127) Kruskall M S, Umlas J. Acquired immunodeficiency syndrome and directed blood donations: a dilemma for American medicine. Archives of surgery. Chicago: 1988; 123:23-25.

(128) Janowitz W R. Safety of the blood supply. Liability for transfusion-associated AIDS. Fournal of legal medicine 1988; 9:611-622.

(129) Swinbanks D. AIDS-contaminated blood: haemophiliacs to sue. Nature $1989 ; 340: 416$.

(130) Silvergleid A J, Leparc G F, Schmidt P J. Impact of explicit questions about high-risk activities on donor attitudes and donor deferral patterns. Results in two community blood centers. Transfusion 1989; 29:362-364.

(131) Macklin R, Friedland G. AIDS research: the ethics of clinical trials. Law, medicine and health care $1986 ; 14: 273-280$.

(132) Mariner W K, Gallo R C. Getting to market: the scientific and legal climate for developing an AIDS vaccine. Law, medicine and health care 1987 ; $15: 17-26$.

(133) Anonymous. Acquired immunodeficiency syndrome (AIDS): 
vaccine development. Weekly epidemiological record 1987; 62:9395.

(134) Weisburd S. AIDS vaccines: the problems of human testing. Science 1987; 131:329-332.

(135) Rothman D J. Ethical and social issues in the development of new drugs and vaccines. Bulletin of the New York Academy of Medicine 1987; 63:557-568.

(136) Barnes D M. Will an AIDS vaccine bankrupt the company that makes it? Science 1986; 233:1035.

(137) Smith L G, Brennan R E. Legal ramifications of the development of an AIDS vaccine. New fersey medicine 1987; 84:702-704.

(138) Grodin M A, Kaminow P V, Sassower R. Ethical issues in AIDS research. $Q R B$ : quality review bulletin 1986; 12:347-352.

(139) American Psychological Association. Ethical issues in psychological research on AIDS. Committee for Protection of Human Participants in Research in co-operation with the Committee on Gay Concerns. Foumal of homosexuality 1986; 13:109-116.

(140) Wright K. AIDS in California: state aid offered for vaccine. Nature 1986; 321:105.

(141) Novick A, Neveloff Dubler N, Landesman S H. Do research subjects have the right not to know their HIV antibody test results? (Three commentaries). IRB: a review of human subjects research 1986; 8:6-9.

(142) Mariner W K. Why clinical trials of AIDS vaccines are premature. American journal of public health 1989; 79:86-91

(143) Barinaga M. Placebos prompt new protocols for AIDS drug tests. Nature 1988; 335:485.

(144) Young F E, Norris J A, Levitt J A, Nightingale S L. The FDA's new procedures for the use of investigational drugs in treatment. Fournal of the American Medical Association 1988; 259:22672270.

(145) Christakis N A. The ethical design of an AIDS vaccine trial in Africa. Hastings Center report 1988; 18:31-37.

(146) Koff W C, Hoth D F. Development and testing of AIDS vaccines. Science $1988 ; 241: 426-432$.

(147) Prince A M, Goodall J, Brotman B, Dienske H, Schellekens H, Eichberg J W. Appropriate conditions for maintenance of chimpanzees in studies with blood-borne viruses: an epidemiologic and psychosocial perspective. Fournal of medical primatology 1989; 18:27-42.

(148) Emanuel E J, Emanuel L L. Is our AIDS policy ethical? [editorial]. American journal of medicine 1987; 83:519-520.

(149) Rosendorf L L, Hatfield S. Acquired immunodeficiency syndrome: rules for pestilential contagion revisited. American journal of infection control 1984; 12:31-33.

(150) Last J M. Ethics, mores and values and AIDS [editorial]. Canadian journal of public health 1987; 78:75-77.

(151) Mustacchi P. SIDA et information. Médecine d'Afrique noire $1987 ; 34: 215-220$

(152) Morse S J, Beneze N L. AIDS and the law. IMF: Illinois medical journal 1987; 171:370-374

(153) Johnson B J, Soskolne C L. AIDS: medicolegal considerations for Canadian hospitals. Canadian Medical Association journal 1986; 135:1091-1096.

(154) Pascal C B. Selected legal issues about AIDS for drug abuse treatment programs. Fournal of psychoactive drugs 1987; 19:1-12.

(155) Horassius J N, Tastevin H, Horassius A. Une bien embarrassante affaire: réflexions à partir des réactions paradoxales du corps médical face au SIDA et à la séropositivité. Information psychiatrique. 1987; 63:203-213.

(156) Dilley J W, Shelp E E, Batki S L. Psychiatric and ethical issues in the care of patients with AIDS. Psychosomatics 1986; $27: 562$ 566.

(157) Tauer C A. AIDS: Human rights and Public Health. Medical anthropology 1989; 10:177-192.

(158) Gillon R. AIDS and medical confidentiality. British medical journal 1987; 294:1675-1677.

(159) Roy D J, Tsoukas C. AIDS and clinical ethics: honoring patients' dignity. Dimensions in health service 1986; 63:32-33.

(160) Fisher E J. Consider the psychosocial consequences of AIDS. Michigan medicine 1986; 85:95-96.

(161) Anonymous. AIDS and the ethics of disclosure [letter]. Medical journal of Australia 1987; 147:522.
(162) Helbert M. AIDS and medical confidentiality [letter]. British medical journal 1987; 295:552.

(163) Marwick C. 'Confidentiality' issues may cloud epidemiologic studies of AIDS. Fournal of the American Medical Association 1983; 250:1945-1946.

(164) Acheson E D. AIDS: a challenge for the public health. Lancet 1986; 1:662-666.

(165) Nelson L P, Album M M. AIDS: children with HIV infection and their families. ASDC: journal of dentistry for children 1987; 54:353-358.

(166) Coggins P R. AIDS: what about testing? Delaware medical journal 1987; 59:373-374.

(167) Winston M, Landesman S H. AIDS and a duty to protect. Hastings Center report 1987; 17:22-23.

(168) Greenway J L. Statement on confidentiality of information. Foumal of American College of Health 1986; 35:131-133.

(169) Blackman J A, Appel B R. Epidemiologic and legal considerations in the exclusion of children with acquired immunodeficiency syndrome, cytomegalovirus or herpes simplex virus infection from group care. Pediatric infectious disease journal 1987; 6:1011-1015.

(170) General Medical Council agrees guidelines on AIDS. British medical journal 1988; 296:1613.

(171) Anonymous. Partner notification for preventing human immunodeficiency virus (HIV) infection - Colorado, Idaho, South Carolina, Virgina. Morbidity and mortality weekly report $1988 ; 37: 393-396,401-402$

(172) Dickens B M. Legal rights and duties in the AIDS epidemic. Science 1988; 239:580-586.

(173) Blendon R J, Donelan K. Discrimination against people with AIDS: the public's perspective. New England journal of medicine 1988; 319:1022-1026.

(174) Presidential Commission on the Human Immunodeficiency Virus Epidemic. Report of the presidential commission on the human immunodeficiency virus. USA: Government Printing Office, 1988.

(175) Dickens B M. Legal limits of AIDS confidentiality. Fournal of the American Medical Association 1988; 259:3449-3451.

(176) Perry S. Warning third parties at risk of AIDS: APA's policy is a barrier to treatment. Hospital and community psychiatry 1989 40:158-161.

(177) Mangione C M, Lo B. Beyond fear. Resolving ethical dilemmas regarding HIV infection. Chest 1989; 95:1100-1106.

(178) Binder R L. AIDS antibody tests on inpatient psychiatric units. American journal of psychiatry $1987 ; 144: 176-181$

(179) Steinbrook R, Lo B, Tirpack J, Dilley J W, Volberding P A. Ethical dilemmas in caring for patients with the acquired immunodeficiency syndrome. Annals of internal medicine 1985; 103:787-790.

(180) GMC considers further advice on treating patients with AIDS. British medical journal 1987; 295:1292.

(181) Cooke M. Ethical issues in the care of patients with AIDS. QRB: quality review bulletin $1986 ; 12: 343-346$.

(182) Jessiman I M. AIDS: a faltering step. British medical journal $1987 ; 295: 267$

(183) Davis V. AIDS: should nurses honor a patient's confidentiality or a partner's right to know? Journal of Christian nursing 1987; 4:4-6.

(184) Steinbrook R, Lo B, Moulton J, Saika G, Hollander H, Volberding P A. Preferences of homosexual men with AIDS for life-sustaining treatment. New England journal of medicine 1986; 314:457-460

(185) Benezech M, Rager P, Lavenu M E, Beylot J, Bourgeois M. Aspects médico-psychologiques de l'information médicale en matière de SIDA: l'exemple des toxicomanes détenus. Annales medico-psychologiques 1988; 146:222-229.

(186) Levine C. Has AIDS changed the ethics of human subjects research? Law, medicine and health care 1988; 16:167-173.

(187) Doyal L, Hurwitz B. The recent BMA ruling on AIDS. The patient's right to informed consent versus the doctor's right to protection. Practitioner 1987; 231:1217-1222.

(188) Hollowell E E, Eldridge J E. The legal obligations for treating or testing for the HIV infection. Foumal of practical nursing 1988; 38:36-40.

(189) Anonymous. Ammalati di AIDS in ospedale: curare in modo 
consapevole e senza paura. Krankenpflege 1987; 80:87-89.

(190) Cox J M. Justice, compassion needed in treating AIDS patients. Health progress 1986; 67:34-37.

(191) Statement of General Medical Council. The doctor's duty towards AIDS patients. Lancet 1987; 1:1274.

(192) When doctors refuse to treat AIDS [editorial]. New York Times 1987 Aug 3: A 16.

(193) O'Reilly M E. Implications of refusing an employer's directives. Focus on critical care 1987; 14:53-54.

(194) Gillon R. Refusal to treat AIDS and HIV positive patients. British medical journal 1987; 294:1332-1333.

(195) Loewy E H. Duties, fears and physicians. Social science and medicine 1986; 22:1363-1366.

(196) Ratzan R M, Schneiderman H. AIDS, autopsies, and abandonment. Fournal of the American Medical Association 1988; 260:3466-3469.

(197) Becker C E, Cone J E, Gerberding J. Occupational infection with human immunodeficiency virus (HIV). Risks and risk reduction. Annals of internal medicine 1989; 110:653-656.

(198) Cotton D J. The impact of AIDS on the medical care system. Fournal of the American Medical Association 1988; 260:519-523.

(199) Geraghty D. AIDS and the physician's duty to treat. Fournal of legal medicine 1989; 10:47-58.

(200) Pellegrino E D. HIV infection and the ethics of clinical care. Foumal of legal medicine 1989; 10:29-46.

(201) Spece R J Jr. AIDS: due process, equal protection, and the right to treatment. Issues in law and medicine $1988 ; 4: 283-344$.

(202) Lo B. Obligations to care for persons with human immunodeficiency virus. Issues in law and medicine 1988; 4:367381.

(203) Zinberg J M. AIDS: The duty to treat. A physician-lawyer's perspective. Mount Sinai joumal of medicine. New York: 1989; 56:259-264.

(204) Preus A. AIDS: The duty to treat. A philosopher's perspective. Mount Sinai journal of medicine (New York) 1989; 56:254-258.

(205) Patterson R. AIDS: The duty to treat. 1988 AMA position Mount Sinai journal of medicine (New York) 1989; 56:250-251.

(206) Gramelspacher G P, Siegler M. Do physicians have professional responsibility to care for patients with HIV disease? Issues in law and medicine 1988; 4:383-393.

(207) Crisp R. Autonomy, welfare and the treatment of AIDS. Fournal of medical ethics 1989; 15:68-73.

(208) Grady C. Ethical Issues in providing nursing care to human immunodeficiency virus-infected populations. Nursing clinics of North America 1989; 24:523-534.

(209) Annas G J. Legal risks and responsibilities of physicians in the AIDS epidemic. Hastings Center report 1988; 18 (suppl): 26-32.

(210) Kim J H, Perfect J R. To help the sick: an historical and ethical essay concerning the refusal to care for patients with AIDS. The American joumal of medicine $1988 ; 84: 135-139$.

(211) Reisman E C. Ethical issues confronting nurses. Nursing clinics of North America. 1988; 23:789-802.

(212) Zuger A, Miles S H. Physicians, AIDS, and occupational risk. Historic traditions and ethical obligations. Foumal of the
American Medical Association 1987; 258:1924-1928.

(213) Arras J D. The fragile web of responsibility: AIDS and the duty to treat. Hastings Center report 1988; 18 (suppl): 10-20.

(214) Annas G J. Not saints, but healers: the legal duties of health care professionals in the AIDS epidemic. American journal of public health 1988; 78:844-849.

(215) Emanuel E J. Do physicians have an obligation to treat patients with AIDS? New England journal of medicine 1988; 318:16861690.

(216) Banks T L. AIDS and the right to health care. Issues in law and medicine 1988 ; 4:151-173.

(217) Freedman B. Health professions, codes, and the right to refuse to treat HIV-infectious patients. Hastings Center report 1988; 18 (suppl): 20-25.

(218) Rozovsky L E, Rozovsky F A. Critical care, AIDS and the law. Canadian critical care nursing journal 1987; 4:16-17.

(219) Wathen B. AIDS: separating fact from fiction [editorial]. Foumal of the American Dental Association 1987; 115:660.

(220) Anonymous. The 'don't tell' mentality [letter]. American journal of nursing 1987; 87:1281-1282.

(221) Ponsford G. AIDS in the OR: a surgeon's view. Canadian Medical Association joumal 1987; 137: 1036-1039.

(222) American Hospital Association. A hospitalwide approach to AIDS. Recommendations of the Advisory Committee on Infections within Hospitals. Infection control 1984; 5:242-248.

(223) Droste T. Koop: AIDS poses ethical dilemmas for physicians. Hospitals 1987; 61:61-62.

(224) Creighton H. Legal aspects of AIDS-Part I. Law for the nurse manager. Nursing management 1986; 17:14-16.

(225) Stoller B. AIDS. Fournal of practical nursing 1985; 35:26-31.

(226) Zuger A. AIDS on the wards: a residency in medical ethics. Hastings Center report 1987; 17:16-20.

(227) Volberding P, Abrams D. Clinical care and research in AIDS. Hastings Center report 1985; 15:16-18.

(228) Lattimer A D. The acquired immunodeficiency syndrome. Issues for hospital and medical staffs. IMF: Illinois medical journal 1987; 171:379-381.

(229) Sowa P E, Miller D. Administrative response to issues of healthcare worker safety and HIV exposure. State of the art reviews: occupational medicine 1989; 4 (suppl): 45-50.

(230) Gurevich I. Acquired immunodeficiency syndrome: realistic concerns and appropriate precautions. Heart lung 1989; 18:107112.

(231) Miller P J, Farr B M. A study of the rate of postexposure human immunodeficiency virus testing in a hospital requiring written informed consent. Foumal of occupational medicine 1989, 31:524-527.

(232) Wugofski L, Mosmiller T E. Establishing an HIV counselling and testing program for health-care workers. Issues and controversies in policy development. State of the art reviews: occupational medicine 1989; 4 (suppl): 103-113.

The complete bibliography can be sent on request. 